\title{
Chemical composition of the volatile oil of Cardiopetalum calophyllum collected in the Cerrado area
}

\author{
Composição química do óleo volátil de Cardiopetalum calophyllum \\ coletada em área de Cerrado
}

\author{
Marcelo Nogueira Xavier ${ }^{I^{*}}$ Cássia Cristina Fernandes Alves ${ }^{\mathrm{I}}$ \\ Cristiane de Melo Cazal ${ }^{I}$ Nathalia Horrana Santos ${ }^{I}$
}

\section{ABSTRACT}

The Annonaceae family consists of 135 genera with diverse species and a large number of chemical compounds arising from the secondary metabolism. However, the chemical composition of the essential oil of several species of the family such as Cardiopetalum calophyllum has not been completely determined. In this study, the essential oils extracted from the leaves, flowers, and fruits of $\boldsymbol{C}$. calophyllum, collected in typical areas of the Cerrado of Goiás, were characterized. The essential oil was extracted by hydrodistillation for $4 \mathrm{~h}$ using a Clevenger apparatus. The chemical analysis was carried out by gas chromatography-mass spectrometry (GC-MS), and the constituents were identified by comparing the spectra and retention index obtained with those available in the literature. Twenty three compounds were identified in the essential oil of leaves; the oxygenated sesquiterpene, spathulenol (28.78\%), was the major compound. Twenty five compounds were identified in the flowers, mainly comprising sesquiterpene hydrocarbons, germacrene- $D$ (37.03\%) and germacrene-B (13.72\%). Seventeen compounds were reported in fruits, mainly comprising sesquiterpene hydrocarbons, germacrene-D (28.19\%) and germacrene-B (20.90\%), and an oxygenated sesquiterpene, spathulenol (11.53\%). This is the first report on the chemical composition of the essential oils from leaves, flowers, and fruits of C. calophyllum.

Key words: essential oil, Annonaceae, chemical composition, imbirinha.

RESUMO

A família Annonaceae é constituída por cerca de 135 gêneros, com uma diversidade extensa de espécies com grande quantidade de compostos químicos diversificados, advindos do metabolismo secundário. Entretanto, as informações sobre a composição química de óleo essencial de várias espécies da família ainda são incipientes, como é o caso da Cardiopetalum calophyllum. $O$ trabalho teve como objetivo caracterizar quimicamente o óleo essencial extraído de folhas, flores e frutos da C. calophyllum, coletadas em áreas típicas do Cerrado goiano. A extração do óleo essencial se deu pelo método de hidrodestilação em aparelho de clevenger por um periodo de 4 horas. A análise química do óleo essencial foi realizada por cromatografia gasosa acoplada à espectrometria de massas (CG-MS) e a identificação dos constituintes pela comparação dos espectros obtidos com os espectros disponíveis na literatura e pelo cálculo do índice de retenção (IR). Foram identificados 23 compostos no óleo essencial das folhas, em que o composto majoritário foi o sesquiterpeno oxigenado espatulenol $(28,78 \%)$; nas flores, foram identificados 31 compostos com predominância dos sesquiterpenos hidrocarbonados germacreno-D (37,03\%) e germacreno-B (13,72\%); e, nos frutos, 17 compostos com predominância dos sesquiterpenos hidrocarbonados germareno-D $(28,19 \%)$ e germacreno-B $(20,90 \%)$ e do sesquiterpeno oxigenado espatulenol $(11,53 \%)$. Este trabalho descreve pela primeira vez a composição química do óleo essencial das folhas, flores e frutos da C. calophyllum, contribuindo significativamente para o conhecimento químico da espécie.

Palavras-chave: óleo essencial, Annonaceae, composição química, imbirinha.

\section{INTRODUCTION}

The Annonaceae family consists of $\sim 2500$ species, grouped in 135 genera, with a pantropical distribution. In Brazil, 386 species belonging to 29 genera exist. The Cerrado is home to 10 genera and 47 species, none of which is endemic to the area, even though some of the genera and species are quite common, such as Annona crassiflora, Duguetia furfuracea, Xylopia aromatica, and Cardiopetalum

\footnotetext{
'Programa de Pós-graduação em Agroquímica, Instituto Federal de Educação Ciência e Tecnologia Goiano, Campus Rio Verde, Avenida Goiânia, Km 1, Zona Rural, 75901-970, Rio Verde, Goiás, Brasil. E-mail: marcelo-biologo@live.com. *Corresponding author. 
calophyllum (LOPES \& MELLO-SILVA, 2014). According to ISHARA \& MAIMONI-RODELLA (2011), the Annonaceae family occupies the $13^{\text {th }}$ place with respect to the number of species per family in the Cerrado.

Some genera are chemically welldocumented, such as Xylopia, where significant concentrations of caryophyllene oxide, $\alpha$-pinene, $\alpha$-terpinene, limonene, spathulenol, germacrene-D, trans- $\beta$-guaiene, and $\beta$-caryophyllene are present in the essential oils extracted from the leaves and fruits (SANTOS, et al. 2004; PONTES et al., 2007; VALTER et al., 2008). Annona genus has also been well-characterized; caryophyllene, camphene, $\alpha$-pinene, and $\beta$-pinene have been identified in the essential oil extracted from the leaves (BANDEIRA et al., 2011; CAMPOS et al., 2014). However, the active substances present in the plants of this family are still investigated (NASCIMENTO et al., 2003; SILVA, 2007; NUNES et al., 2012; ALMEIDA et al., 2014; KRINSKI et al., 2014). C. calophyllum is a semideciduous species flowering between the months of August and October, with the peak flowering in September and fruiting between the months of January and April (SILVA et al., 2009; ELIAS, 2010). C. calophyllum is represented by trees and shrubs with heights ranging from 1.5 to $12 \mathrm{~m}$, commonly known as imbira, imbirinha, coast pepper, red pepper, among others (FECHINE et al., 2002; SILVA et al., 2009). Several communities use $\boldsymbol{C}$. calophyllum to treat some diseases such as bronchitis, sinusitis, dysmenorrhea, and fever, and as a carminative, both in the form of syrup and tea (NASCIMENTO et al., 2003; COELHO et al., 2009; COSTA, 2011; COSTA et al., 2013).

Biological studies of $\boldsymbol{C}$. calophyllum have shown diverse potential applications. FOURNET et al. (1994) reported the leishmanicidal effect of ethanol extract of leaves of $\boldsymbol{C}$. calophyllum on Leishmania amazonensis, the etiological agent of cutaneous leishmaniasis. COSTA (2011) reported the biocidal effect of methanol extract of fruits of $\boldsymbol{C}$. calophyllum in Aedes aegypti larvae on the third stage of development. SILVA et al. (2008) evaluated the action of eight organic extracts from various organs of $\boldsymbol{C}$. calophyllum on the in vitro mycelial growth of six pathogenic fungi; the ethanol and hexane extracts of the stem bark inhibited growth.

Chemical composition of essential oil of C. calophyllum has not been reported. The aim of this study was to compare the chemical composition of volatile oils extracted from leaves, flowers, and fruits of $\boldsymbol{C}$. calophyllum collected in Cerrado areas.

\section{MATERIALS AND METHODS}

Plant material

Leaves, flowers, and fruits of $\boldsymbol{C}$. calophyllum were collected in March, September, and December 2014, respectively, in the city of Rio Verde, state of Goiás, a native Cerrado area in the Universidade de Rio Verde (UniRV). Species was identified by biologists Odirlei Simões and Marcelo Nogueira, and the exsiccatae were deposited in the herbarium of the Universidade Estadual de Montes Claros (UNIMONTES), record number 3815. The material was transferred to the Natural Products Chemistry Laboratory of the Instituto Federal de Ciência, Educação e Tecnologia de Goiás, Rio Verde campus, where it was screened and the damaged material was discarded.

\section{Extraction of volatile oil}

The oil was obtained by hydrodistillation for $4 \mathrm{~h}$, following the method described by SIQUEIRA et al. (2011). The essential oil was extracted from the hydrolat with dichloromethane, and trace water was removed using anhydrous sodium sulfate. Salt was removed by filtration, and the solvent was removed by evaporation at room temperature. The essential oil was stored at $-4^{\circ} \mathrm{C}$ until the analysis.

Identification of the chemical components

The essential oils were analyzed by coupled gas chromatography-mass spectrometry (GC-MS, Shimadzu QP-5000). A capillary column DB-5 $(30.0 \mathrm{~m} \times 0.25 \mathrm{~mm} \times 0.25 \mu \mathrm{m})$ was used as follows: injector at $220^{\circ} \mathrm{C}$, detector at $240^{\circ} \mathrm{C}$, split injection (1:20), volume of injection: $1 \mu \mathrm{L}$, temperature gradient from $60^{\circ} \mathrm{C}$ to $300^{\circ} \mathrm{C}$, with an increment of $3^{\circ} \mathrm{C} \mathrm{min}^{-1}$.

Compounds were identified by comparing their mass spectra with a database (NIST 11 library) and also by comparing their retention indices (RI) with those reported in the literature (ADAMS, 2007). The RI were determined using the calibration curve of a series of n-alkanes (C10-C29) injected under the same chromatographic conditions as the samples.

\section{RESULTS AND DISCUSSION}

This is the first report on the chemical composition of the essential oil of leaves, flowers, and fruits of $\boldsymbol{C}$. calophyllum, thus contributing significantly, to the knowledge of the species. The list of special metabolites identified in the essential oil extracted from the leaves, flowers, and fruits of $\boldsymbol{C}$. 
calophyllum, their relative amounts, and IR spectral data are shown in table 1. From the GC-MS data, 23 compounds were identified in the essential oil of leaves, where the major compound was spathulenol
$(28.78 \%)$. Twenty five compounds were identified in the flowers, mainly comprising germacrene-D $(37.03 \%)$ and germacrene-B (13.72\%). Seventeen compounds were identified in the fruits, mainly

Table 1 - Compounds identified in the essential oil of the leaves, flowers, and fruits of $\boldsymbol{C}$. calophyllum, collected in a typical area of Cerrado in the city of Rio Verde in 2014.

\begin{tabular}{|c|c|c|c|c|}
\hline \multirow{2}{*}{ Compound } & \multirow{2}{*}{ RI } & \multicolumn{3}{|c|}{-Area (\%)- } \\
\hline & & Leaves & Flowers & Fruits \\
\hline cis- $\beta$-ocimene & 1007 & - & 0.06 & 0.10 \\
\hline$\beta$-linalool & 1052 & - & 0.13 & - \\
\hline 4-terpineol & 1130 & - & 0.15 & - \\
\hline$p$-Cimen-8-ol & 1138 & - & 0.17 & - \\
\hline Cryptone & 1140 & 0.43 & - & 0.45 \\
\hline$\delta$-elemene & 1298 & - & 1.18 & 1.16 \\
\hline Eugenol & 1320 & - & 2.40 & - \\
\hline Copaene & 1339 & 0.17 & 0.57 & 0.37 \\
\hline$\beta$-copaene & 1354 & - & 0.18 & - \\
\hline$\beta$-elemene & 1356 & 0.22 & 0.25 & 0.47 \\
\hline$\alpha$-gurjunene & 1363 & - & 0.13 & - \\
\hline Caryophyllene & 1384 & 1.03 & 5.58 & 2.40 \\
\hline$\beta$-gurjunene & 1397 & - & 0.18 & - \\
\hline Alloaromadendrene & 1404 & 0.84 & 0.90 & 0.66 \\
\hline$\alpha$-guaiene & 1409 & - & 0.16 & - \\
\hline Humulene & 1419 & 0.44 & 0.98 & 0.40 \\
\hline$\beta$-copaene & 1443 & 0.76 & - & - \\
\hline Germacrene-D & 1448 & 0.43 & 37.03 & 28.19 \\
\hline$\beta$-selinene & 1453 & 0.38 & - & - \\
\hline Isoledene & 1458 & - & 0.27 & - \\
\hline Viridiflorene & 1462 & 1.08 & - & - \\
\hline Germacrene-B & 1464 & - & 13.72 & 20.90 \\
\hline$\alpha$-muurolene & 1468 & 0.21 & 0.51 & - \\
\hline$\alpha$-bulnesene & 1472 & - & - & 0.72 \\
\hline$\gamma$-muurolene & 1481 & 0.74 & 0.18 & - \\
\hline$\delta$-cadinene & 1491 & 0.62 & - & 0.71 \\
\hline$\gamma$-gurjunene & 1523 & - & 3.41 & - \\
\hline Spathulenol & 1544 & 28.78 & 0.57 & 11.53 \\
\hline Viridiflorol & 1550 & 9.99 & 0.77 & 2.02 \\
\hline Elemol & 1560 & 0.76 & - & - \\
\hline Caryophyllene oxide & 1575 & 1.99 & - & 0.81 \\
\hline Cubenol & 1583 & 0.67 & - & - \\
\hline Ent-spathulenol & 1593 & 2.10 & - & 1.94 \\
\hline$\tau$-cadinol & 1605 & 1.58 & 0.43 & - \\
\hline (-)-Isolongifolol acetate & 1617 & 5.06 & 0.71 & 1.01 \\
\hline$(Z, E)$-farnesol & 1634 & 6.51 & - & - \\
\hline Aromadendrene oxide 2 & 1692 & 1.68 & - & - \\
\hline Monoterpenes & & 0.43 & 0.51 & 0.55 \\
\hline Sesquiterpenes & & 66.04 & 70.11 & 73.29 \\
\hline
\end{tabular}

RI: retention index. 
comprising germacrene-D (28.19\%), germacrene-B (20.90\%), and spathulenol (11.53\%).

The sesquiterpenes represent the majority of the compounds identified in different organs of $\boldsymbol{C}$. calophyllum (Table 1), as observed in other species of the Annonaceae family. FEITOSA et al. (2009) characterized the essential oil present in the branches of Rollinia leptopetala, lacking monoterpenes, whereas sesquiterpenes, particularly oxygenated sesquiterpenes, were abundantly present. PONTES et al. (2007) evaluated the acaricidal activity of the essential oil obtained from the leaves of Xylopia sericea; $\sim 95 \%$ of the oil comprised of a complex mixture of sesquiterpenes. CAMPOS et al. (2014) also reported a predominance of sesquiterpenes in the essential oils of Annona emarginata and Annona squamosa.

PEREIRA \& TEIXEIRA (1999) attributed the presence of sesquiterpenes in secondary metabolites to the adaptation of the plant species to the environment, i.e., against herbivores, pathogens, and encrusting organisms. In a study that focused on the essential oil of Duguetia furfuracea, VALTER et al. (2008) noted that the presence of oxygenated sesquiterpenes is not common in Cerrado species because of the specific conditions of the biome. However, this was not observed in the essential oil of $\boldsymbol{C}$. calophyllum, where spathulenol was observed in high concentrations in more than one organ.

Spathulenol has been reported as the major compound in the essential oil extracted from the leaves of the other species of the Annonaceae family, such as Guatteria schomburgkiana (TRIGO et al., 2007), Annona vepretorum (COSTA et al., 2012), Rollinia leptopetala (COSTA et al., 2008) and Duguetia furfuracea (VALTER et al., 2008), among others. High concentrations of spathulenol have also been reported in the essential oil of the species of the genera Annona, Artabotrys, Cleistopholis, Goniothalamus, Piptostigma, Uvaria, and Xylopia (TRIGO et al., 2007). Moreover, spathulenol was observed in high concentrations $(11.53 \%)$ in the fruit of . calophyllum. Because of this predominance of spathulenol, LIMA et al. (2004) and SIQUEIRA et al. (2011) recommended the use of spathulenol as a chemical marker of the Annonaceae family.

Germacrene-D is also common in other species of the Annonaceae family. VALTER et al. (2008) reported the presence of significant concentrations of germacrene-D in Duguetia furfuracea. CASTRO et al. (2006) and SOUZA et al. (2007) suggested that pollinators were attracted to these plants because of the presence of germacrene- $\mathrm{D}$, because its chemical backbone mimics the sex pheromones of insects, explaining the high concentration of germacrene-D in the essential oils of the flowers and fruits of C. calophyllum.

Other less abundant sesquiterpenes, with known biological activities, were also identified in the essential oil of the three organs (leaf, flower, and fruit) of $\boldsymbol{C}$. calophyllum in different concentrations (Table 1). Copaene exhibits deterrent activity against insects and has a great industrial value because of its characteristic aroma (PEREIRA et al., 2008). Caryophyllene exhibits several biological activities such as spasmolytic, anti-inflammatory, and anesthetic activities (LIMBERGER et al., 2004). Further, humulene is described in the literature as an insecticide, antimicrobial, antioxidant, and anticancer compound (ALMEIDA et al., 2011).

\section{CONCLUSION}

Essential oil of leaves, flowers, and fruits of C. calophyllum consists of a complex mixture of mono and sesquiterpenes, with a predominance of the latter. The major constituents identified were spathulenol $(28.78 \%)$ in essential oil of leaves, germacrene-D (37.03\%) and germacrene-B $(13.72 \%)$ in flowers, and germacrene-D (28.19\%), germacrene-B (20.90\%), and spathulenol (11.53\%) in essential oil of fruits.

\section{REFERENCES}

ADAMS, R.P. Identification of essential oil components by Gas Chromatography/Mass Spectrometry. Carol Stream: Illinois, 2007. 4v

ALMEIDA, M.F.O. et al. Constituintes químicos e atividade leishmanicida de Gustavia elliptica (Lecythidaceae). Química Nova, São Paulo, v.34, n.7, p.1182-1187, 2011. Available from: $<$ http://bit.ly/1dCRy5j>. Accessed: May 30, 2015. doi: 10.1590/ S0100-40422011000700015.

ALMEIDA, J.R.G. da S. et al. Atividade antioxidante, citotóxica e antimicrobiana de Annona vepretorum Mart. (Annonaceae). Revista Brasileira de Fruticultura, Jaboticabal, v.36, Ed. esp., p.258-264, 2014. Available from: <http://bit. 1y/1x3PeZI>. Accessed: Nov. 30, 2014. doi: 10.1590/S010029452014000500030 .

BANDEIRA, J.M. et al. Composição do óleo essencial de quatro espécies do gênero Plectranthus. Revista Brasileira de Plantas Medicinais, Botucatu, v.13, n.2, p.157-164, 2011. Available from: $<$ http://bit.ly/1FJGhZZ>. Accessed: May 25, 2015. doi: 10.1590/ S1516-05722011000200006.

CAMPOS, F.G. et al. Characterization of the chemical composition of the essential oils from Annona emarginata 
(Schltdl.) H. Rainer 'terra-fria' and Annona squamosa L. Revista Brasileira de Fruticultura, Jaboticabal, v.36, Ed. esp., p.202-208, 2014. Available from: <http://bit. ly/1wkiVso>. Accessed: May 25, 2015. doi: 10.1590/S010029452014000500024.

CASTRO, D.P. et al. Não preferência de Spodopptera frugiperda (Lepdoptera: Noctuidae) por óleos essenciais de Achillea millefolium L. e Thymus vulgaris L. Revista Brasileira de Plantas Medicinais, Botucatu, v.8, n.4, p.2732, 2006. Available from: <http://bit.ly/1w3jtQb $>$. Accessed: Nov. 16, 2014.

COELHO, A.A.M. et al. Efeitos de extratos de plantas do Cerrado em Dipetalogaster máxima (Uhler) (Hemíptera, Reduviidae). Revista Brasileira de Entomologia, Curitiba, v.53, n.3, p.444-451, 2009. Available from: <http://bit ly/1AR7YME >. Accessed: Nov. 25, 2014. doi: 10.1590/S008556262009000300020 .

COSTA, E.V. et al. Chemical composition and antimicrobial activity of the essential oils of the Amazon Guatteriopsis species. Phytochemistry, Amsterdã, v.69, n.1, p.1895-1899, 2008. Available from: $<$ http://bit.ly/1G5rqXx $>$. Accessed: Nov. 15, 2014. doi: 10.1016/j.phytochem.2008.03.005.

COSTA, E.V. et al. Essential oil from the leaves of Annona vepretorum: chemical composition and bioactivity. Natural Product Communications, Ohio, v.7, n.2, p.265-269, 2012. Available from: $<$ http://1.usa.gov/1InahyF $>$. Accessed: May 25, 2015.

COSTA, M. da S. O vetor da dengue como objeto de atuação dos agentes de vigilância ambiental e de pesquisas com plantas inseticidas do Cerrado, em Tangará da Serra, MT. 2011. 74f. Dissertação (Mestrado em Ciências Ambientais) - Curso de Pósgraduação em Ciências Ambientais, Universidade do Estado de Mato Grosso, MT.

COSTA, M. da S. et al. Anonáceas provocam mortalidade em larvas de Aedes aegypti (Linnaeus, 1762) (Diptera: Culicidae). Revista Brasileira de Biociências, Porto Alegre, v.11, n.2, p.184-190, 2013. Available from: <http://bit.ly/1ytzzRk>. Accessed: Nov. 11, 2014.

ELIAS, M.A.D.S. Ecologia reprodutiva de Cardiopetalum calophyllum (Annonaceae) em fragmentos de Cerrado do Brasil Central. 2010. 48f. Dissertação (Mestrado em Ecologia e Evolução). Programa de Pós-graduação em Ecologia e Evolução, Universidade Federal de Goiás-GO.

FECHINE, I.M. et al. Alcalóides de Duguetia trunciflora Maas (Annonaceae). Revista Brasileira de Farmacognosia Maringá, v.12, supl., p.17-19, 2002. Available from: <http://bit. ly/1vCYG7j>. Accessed: Nov. 11, 2014. doi: 10.1590/S0102695X2002000300009.

FEITOSA, E.M.A. et al. Chemical composition and larvicidal activity of Rollinia leptopetala (Annonaceae). Journal of the Brazilian Chemical Society, Campinas, v.20, n.2, p.375-378, 2009. Available from: <http://bit.ly/1vu2nqT >. Accessed: May 23, 2015. doi: 10.1590/S0103-50532009000200024.

FOURNET, A. et al. Leishmanicidal and trypanocidal activities of Bolivian medicinal plants. Journal of Ethnopharmacology, Leiden, v.41, p.19-37, 1994. Available from: <http://bit. ly/1AQQB3j>. Accessed: May 26, 2015.
ISHARA, K.L.; MAIMONI-RODELLA, C.S. Pollination and dispersal systems in a Cerrado remnant (Brazilian Savanna) in southeastern Brazil. Brazilian Archives of Biology and Technology, Curitiba, v.54, n.3, p.629-642, 2011. Available from: $<$ http://bit.ly/18113KI>. Accessed: Nov. 30, 2014.

KRINSKI, D. et al. Potencial inseticida de plantas da família Annonaceae. Revista Brasileira de Fruticultura, Jaboticabal, v.36, Ed. esp., p.225-242, 2014. Available from: <http://bit. ly/1wWWojJ $>$. Accessed: Nov. 30, 2014. doi: 10.1590/S010029452014000500027.

LIMA, M.A. et al. Alkaloids and volatile constituents from Guatteria poeppigiana. Biochemical Systematics and Ecology, Amsterdã, v.32, n.3, p.347-349, 2004. Available from: <http:// bit.ly/1BrpZVi>. Accessed: Nov. 15, 2014. doi: 10.1016/j. bse.2003.08.006.

LIMBERGER, R.P. et al. Óleos voláteis de espécies de Myrcia nativas do Rio Grande do Sul. Química Nova, São Paulo, v.27, n.6, p.916-919, 2004. Available from: <http://bit. ly/1EGFSU7>. Accessed: May 29, 2015. doi: 10.1590/S010040422004000600015 .

LOPES, J.D.C.; MELLO-SILVA, R. Diversidade e caracterização das Annonaceae do Brasil. Revista Brasileira de Fruticultura, Jaboticabal, v.36, Ed. esp., p.125-131, 2014. Available from: $<$ http://bit.ly/1wpbbir>. Accessed: Nov. 11, 2014. doi: 10.1590/ S0100-29452014000500015.

NASCIMENTO, F.C. et al. Acetogeninas de anonáceas isoladas de folhas de Rollinia laurifólia. Química Nova, São Paulo, v.26, n.3, p.319-322, 2003. Available from: <http://bit. 1y/1ys6D1d >. Accessed: Nov. 11, 2014. doi: 10.1590/S010040422003000300006 .

NUNES, C. dos R. et al. Flavonoides em Annonaceae: ocorrência e propriedades biológicas. Vértices, Campos dos Goytacazes, v.14, n.1, p.39-57, 2012. Available from: <http://bit.ly/1ARp8d1>. Accessed: Nov. 30, 2014.

PEREIRA, C.P.; TEIXEIRA, V.L. Sesquiterpenos das algas marinhas Laurencia lamouroux (CERAMIALES, RODOPHYTA) 1. Significado ecológico. Química Nova, São Paulo, v.22, n.3, p.369-374, 1999. Available from: <http://bit. ly/1PU3uk5>. Accessed: May 29, 2015. doi: 10.1590/S010040421999000300015 .

PEREIRA, F.J. et al. Isolamento, composição química e atividade anti-inflamatória do óleo essencial do pericarpo de Copaifera langsdorffii Desf. de acordo com hidrodestilações sucessivas. Latin American Journal of Pharmacy, Buenos Aires, v.27, n.3, p.369-374, 2008. Available from: <http://bit.ly/1HTYJm9>. Accessed: May 27, 2015. doi: 10915/7629.

PONTES, W.J.T. et al. Atividade acaricida dos óleos essenciais de folhas e frutos de Xylopia sericea sobre o ácaro rajado (Tetranychus urticae KOCH). Química Nova, São Paulo, v.30, n.4, p.838-841, 2007. Available from: $<$ http://bit.ly/1 coUwZJ $>$. Accessed: May 27, 2015. doi: 10.1590/S0100-40422007000400015.

SANTOS, B.R. et al. Aspectos da anatomia e do óleo essencial em folhas de pindaíba (Xylopia brasiliensis Spreng.). Ciência e Agrotecnologia, Lavras, v.28, n.2, p.345-349, 2004. Available from: <http://bit.ly/1G5JsLa>. Accessed: May 27, 2015. doi: 10.1590/S1413-70542004000200014. 
SILVA, C.S.P.da. As plantas medicinais no município de Ouro Verde de Goiás, GO, Brasil: uma abordagem etnobotânica. 2007. 175f. Dissertação (Mestrado em Botânica) - Curso de Pósgraduação em Botânica, Universidade de Brasília, DF.

SILVA, M.S. et al. Fungos patogênicos de algodão, soja e trigo são sensíveis a extratos orgânicos de planta nativa do Cerrado do gênero Cardiopetalum (Família Annonaceae). In: SIMPÓSIO NACIONAL DO CERRADO, 9.; SIMPÓSIO INTERNACIONAL DE SAVANAS TROPICAIS, 2.; 2008, Brasília, DF. Available from: <http://bit.ly/1vhe81H>. Accessed: May 27, 2014.

SILVA, M.S.da. et al. Alcalóides e outros constituintes de Xylopia langsdorffiana (Annonaceae). Química Nova, São Paulo, v.32, n.6, p.1566-1570, 2009. Available from: <http://bit. ly/1yYGOn5>. Accessed: Nov. 11, 2014. doi: 10.1590/S010040422009000600040.

SIQUEIRA, C.A.T. et al. Chemical constituents of the volatile oil from leaves of Annona coriácea and in vitro antiprotozoal activity. Revista Brasileira de Farmacognosia, Curitiba, v.21, n.1, p.33-
40, 2011. Available from: <http://bit.ly/1CWtwg7>. Accessed: Nov. 16, 2014. doi: 10.1590/S0102-695X2011005000004.

SOUZA, T.J.T. et al. Composição química e atividade antioxidante do óleo volátil de Eupatorium polystachyum DC. Revista Brasileira de Farmacognosia, Curitiba, v.17, n.3, p.368-372, 2007. Available from: <http://bit. ly/1ADMVBU>. Accessed: May 29, 2015. doi: 10.1590/S0102$695 \times 2007000300011$.

TRIGO, J.R. et al. Óleos essenciais de espécies de Annonaceae que ocorrem no Pará: Guatteria schomburgkiana Mart. e Pseudoxandra cuspidata Maas. Revista Brasileira de Plantas Medicinais, Botucatu, v.9, n.3, p.113-116, 2007. Available from: $<$ http://bit.ly/1yF98vO >. Accessed: Nov. 14, 2014.

VALTER, J.L. et al. Variação química no óleo essencial das folhas de seis indivíduos de Duguetia furfuracea (Annonaceae). Revista Brasileira de Farmacognosia, Curitiba, v.18, n.3, p.373-378, 2008. Available from: <http://bit.ly/1yF8Uov>. Accessed: Nov. 16, 2014. doi: 10.1590/S0102-695X2008000300011. 